SHS Web of Conferences 12, 01002 (2014)

DOI: $10.1051 /$ shsconf $/ 20141201002$

C) Owned by the authors, published by EDP Sciences, 2014

\title{
A Critical Analysis on Evolution of Branding Destination in Langkawi Island
}

\author{
Mohd Fadil Mohd Yusof ${ }^{1}$, Hairul Nizam Ismail ${ }^{2}$ and Raja Norliana Raja Omar ${ }^{3}$ \\ ${ }^{1,3}$ Faculty of Entrepreneurship and Business, Dept. of Tourism and Hospitality, Universiti Malaysia \\ Kelantan, 16100 Kota Bharu, Kelantan, Malaysia \\ ${ }^{2}$ Faculty of Built Environment, Universiti Teknologi Malaysia, 81310 UTM Johor Bahru, Johor, \\ Malaysia
}

\begin{abstract}
The purpose of this paper is to highlight the branding efforts by Langkawi Island based on various slogans and taglines used from 1974 until present. Secondary sources such as government reports, destination marketing organization websites, brochures and previous studies were referred to identify those slogans. This paper argues that destination branding process is not as easy as most destination marketing thought. The process is complex and it may need involvement from various stakeholders such as local population and tourism operators. Based on the various slogans identified, this paper argues that too many slogans and taglines are used and thus they may create confusion among host population, tourism operators as well as the tourists in terms of what are the actual core values of the island. The paper concludes with a suggestion that an empirical research is needed to confirm whether all these slogans or brands used are endorsed and supported by the internal stakeholders (e.g. host community, tourism operators) as well as in agreement with what as being perceived by the tourists.
\end{abstract}

\section{Introduction}

Branding a destination is arguably one of the important tools that can assist a destination to compete more effectively for visitors and to enhance a destination's overall image. Using a brand, destinations can differentiate with other similar destinations. Due to the competitive nature of the tourism industry, branding is becoming one of the important marketing strategies for a destination in offering various products and services to the tourists. Destination branding is not new and the concept has been explored since in the 90s. More and more efforts with a significant amount of investment are putting into branding a destination to attract more visitors and investors to come [1]. Branding a destination is a complex process indeed and it is not simply developing brand slogans and logos as most of the destinations are currently doing [2]. Such creativity driven branding that applies few creative ideas such as catchy slogans and interesting logos are important but it is still limited in terms of understanding the holistic approach of branding process. Stressing on creative advertising and highlighting visual elements such as destination logos and symbols are not sufficient in building a destination brand. Furthermore, projecting clear and consistent image to the diverse market segmentation requires certain brand identity characteristics that are unique from other destinations. Studies on destination branding are abundant; however, less research explored on the effectiveness of 
a destination brand from stakeholders' perspectives and the linkages between destination brand identity and destination images (projected and perceived images).

A study by Cai [3] is one of the earliest studies on destination branding. Cai [3] argues that 'recognition of the difference between destination branding and forming or building an image is fundamental to the introduction of branding to tourism marketing studies'. Destination image making and destination branding are related concepts but they are not the same. However, destination image may help tourist in making preferences of a destination and to motivate them to make informed choices. Destination marketers have spent a lot of time and investment in creating strong and positive images and destination image making may be further enhanced through branding strategy especially in building strong positive image for potential and current visitors [3].

Thus, this article aims to describe the destination branding efforts of Langkawi Islands by analyzing the different names and slogans used to promote the islands since the 70 s until present. Government reports, online brochures and other promotional materials as well as previous studies of Langkawi were examined to present some of the projected images of the island and various slogans used to promote the island.

\section{Destination branding process}

Branding a destination is not an easy process. Tourism literature indicate that destination branding is very complex but yet it contributes to strong image development among visitors and supports destination marketers in measuring achievements[4]. In order to brand a destination, there are several importance steps to be undertaken. Hudson and Ritchie [4] in their studies about branding Canada highlight four steps of branding the destination brand experience which indicate that branding exercise require multi-stages and very strategic in nature.

\begin{tabular}{|l|l|l|l|l|}
\hline $\begin{array}{l}\text { Assessing the } \\
\text { destination } \\
\text { brand's current } \\
\text { situation }\end{array}$ & $\begin{array}{l}\text { Developing a } \\
\text { brand } \\
\text { identity and } \\
\text { brand } \\
\text { promise }\end{array}$
\end{tabular}

Figure 1 The four-step of building the destination brand experience [4]

According to Hudson and Ritchie [4], the first stage of building a destination brand requires destination marketers to identify 'the core values of the destination and its brand'. These core values are interpreted as destination brand identity which the image projected is congruence among visitors, tourism operators and host community. If the brand attributes are perceived differently among these stakeholders, it may create confusion especially among visitors and tourism operators. For example, if a destination is to position itself as a family destination but yet it brand attributes mostly indicate that it is more inclined towards wild and adventure destination, such a brand may not be successful in the market. Therefore, it is necessary for destination marketers to conduct series of research project investigating the brand attributes or what the destination can offer to the visitors by asking relevant questions from potential or existing tourists, tourism operators, destination marketing organization members, or host community [4]. The next step of branding a destination is to develop a brand identity and brand promise based on the information obtained from step one.

According to Pike [5], there are three importance interrelated components of the destination process. The first key component, brand identity represents the image of a destination desired by the brand owners or strategists. The purpose of having an identity is for a destination to identify and position itself or its products and services to the tourists [6]. Having an effective brand identity indicates that a destination possesses a strong and distinctive character which it able to deliver emotional power beyond a mental image. The source of the destination identity or desired image is 
relied upon the destination stakeholders. In short, brand identity for a destination communicates about how a destination to be perceived as what the brand owners wish for. Brand identity also provides brand features and its beneficial attributes as well the symbolic, experiential, social, and emotional values of the place [7].

A study by Clark, Clark and Jones [8] on small destination such as Athens, Georgia outlines 17 points of branding process using step by step approach and suggests ways to reduce the costs of branding for that particular destination. This process involves firstly with the setting up branding committee and getting the involvement of local representatives and other relevant stakeholders in order to get the right theme and brand promise before finally execute the brand. Therefore, the roles of various stakeholders in destination branding process are critical. It is mentioned that from the previous literature, stakeholder support and commitment to the brand are the main ingredients of successful destination branding. For example, a study by Bregoli [9] on the relationships between stakeholder coordination and destination branding process suggested that more efforts to be taken by destination marketing organizations to promote the destination brand to the stakeholders in order for the brand will be adopted and applied inn their businesses. Wheeler [6] argue that branding process theoretically and practically is still insufficient due to less consideration towards the whole values of destination has. In their study, important values such as social, cultural, historic, geographic, symbolic, environmental, and economic may contribute to a powerful destination branding strategy. Focusing merely on consumer driven branding strategy may not be sufficient in understanding the branding process.

\section{Langkawi Islands as a study case}

Langkawi Archipelago Island has a total population of 103,075 people where the majority of the population is Malay ethnics represented by $90 \%$ of the total population; the Chinese is $7 \%$ and followed by the Indians and others 3\%. Of the 104 islands available, only three islands are inhibited: Pulau Langkawi (the main island), Pulau Tuba and Pulau Dayang Bunting. There are six districts located on the main island: Mukim Kuah, Padang Matsirat, Ayer Hangat, Bohor, Ulu Melaka and Kedawang. Previously in the $90 \mathrm{~s}$, in terms of the economic activities, local people mainly involved in agriculture and fishing activities but currently, the tourism and hospitality industry seems to dominate the island's economy where more local people are working and getting involved in construction, transport, commerce and hotels [10]. Geographically, the coastal area of Langkawi Island consists of flat, alluvial plains punctuated with limestone ridges. Two thirds of the island is dominated by forestcovered mountains, hills and natural vegetation. Therefore, Langkawi Island is very potential to be developed as a unique tourism destination with this spectacular natural ecological beauty and diverse landscapes.

Before discussing about branding attempts by the island to become an international tourism destination, it is important to briefly discuss on how tourism has become in important economic sector for the island. There are several phases of tourism development recorded in the literature pertaining to Langkawi's tourism industry [i.e. 10-11]. However, before the islands embarked on the tourism industry, local population were mostly involved in fishing activities, rubber plantations and marble quarrying activities [10]. The first phase was initiated since 1975 under Malaysia Tourism Master plan developed by the international consultant (Marwick Mitchell and Company) but the proposals suggested in the plan failed to materialize [11]. The second phase started in the $80 \mathrm{~s}$ where a part of the island was selected to be developed as an international hotel but due to the economic recession the tourism development there was interrupted. However, in year 1987, the Langkawi islands was accorded as a duty free island and subsequently tourism from that year onwards tourism development there went up significantly in terms of the number of tourism project recorded and the arrival of domestic and international travels [11]. Langkawi is recognised as an island that provides pristine beaches and the sea with good hot and sunny weather all year along. Its unique geographic landscapes and natural scenery coupled with natural resources and the collection of myths and legends provide an opportunity for the island to be branded as a premier tourism destination in the country. 


\section{Branding Langkawi as an international tourism destination}

Langkawi Island is a very popular tourism destination in Malaysia. The island is famously known as Mahsuri Legendary Island or Island of Legends among local people. The island's history of Mahsuri, a young lady who had wrongly killed because of adultery accusation was part of the history lesson taught in the Malaysian history textbook. This story of myths and legends were among very strong unique selling points of the island among local visitors. Furthermore, as a tourism icon in the country, the island has many attractions to offer to the visitors in terms of its natural attractions, built facilities (e.g. Langkawi Cable Car, Underwater world, duty free zones etc.), international events (e.g. LIMA, Iron Man) and so on. However, to compete with other successful and established tourism destinations such as Bali, Phuket, Maldives or even Hawaii, relying on those attractions alone is not sufficient. It needs to brand or rebrand itself and to position in such a way that visitors may see the uniqueness of the island.

Most studies on Langkawi Island focuses on tourism development on the island and its impact to the local society. There are several studies pertaining to local people attitudes towards tourism development take place in Langkawi and local involvement in tourism planning on the island [i.e. 1115]. However fewer studies on marketing and projected image of the island are reported. Studies about marketing related to the island are normally conducted from the tourism provider's perspective such as hotel marketing strategies [16-17] but not from other important stakeholders such as local residents or small tourism operators. However, Razak [18] discussed the projected image of Langkawi and how it was represented on various brochures published from as early as 1969 to 2009 . The study indicates that Langkawi has been using the theme 'Island of Legends' since as early as 1969 before a new theme Langkawi Geopark appear on the brochures starting from mid-2007. However, the study only reflected what appears on the brochures but not what local people or tourism operators think of the actual identity or core values of the island.

Based on the Langkawi Tourism Blueprint 2011-2015 prepared by the Economic Planning Unit [9], marketing and branding is one of the important initiatives to be undertaken by the island in order to compete with other established island destinations such as Bali, Phuket or Hawaii. Based on the report, it is recognized that local participation in the tourism development of the island is still low and more concerted effort is needed to coordinate public and private participation in tourism development. In the blueprint, it is identified that branding and marketing is one of the major issues to be addressed in order to develop the island as a competitive destination. The report highlights that Langkawi does not have a strong brand and it provides little differentiation compare to other island destinations. The report suggests that marketing campaign has to be improved in terms of marketing channels and brochures of the island to be revised as tourists friendly brochures. The reports, however, does not clearly mention what are the specific contents to be included in the promotional materials and the specific theme or brand that may agree with what the stakeholders aspire for.

Langkawi Island arguably has been gone through series of branding activities since mid-70s where the island was first branded as the islands of legends destination. In year 1987, the island was accorded a duty free island and subsequently it was promoted as a duty free island. The next branding effort was done by the state government of Kedah where the island was declared as first 'Tourism City' in Malaysia in year 2001. In year 2007, Langkawi was awarded Geopark status by UNESCO and consequently the island was promoted as a Geopark destination hoping to be recognised as a global island destination. The latest series of branding effort was took place recently in year 2012 where the island was branded as nature and eco destination under the brand 'Naturally Langkawi'.

As Table 1 shows, Langkawi is promoted using different names and slogans by associating the island mainly with tales of myths and legends, in the 1980-2000, the island projected another image by broadening Langkawi's tourism product range to attract mass tourists for shopping and business markets for attending special events and conferences (e.g. Langkawi International Dialogue, Langkawi International Maritime and Aerospace Exhibition (LIMA) event. In year 2007, Langkawi launched a new promotional campaign abroad with a tagline 'Langkawi Geopark' destination after it had received a full endorsement by UNESCO as a Geopark destination. Langkawi Geopark is the first Geopark in the country and South East Asia and the 52nd in the Global Geopark Network (GGN) 
[22]. The geopark concept was formally introduced by the Kedah state government in year 2006 with the assistance of LADA and the National University of Malaysia (UKM)'s team of geo-heritage researchers [23]. The main purpose of declaring the island as a geopark destination is to ensure the conservation of Langkawi's natural resources, as well enhancement of local community livelihoods, in the midst of a period of rapid tourism development [23]. Langkawi Geopark is not only a brand but a development tool that promotes conservation and sustainable economic development [24]. In year 2012, there was another campaign launched by the Island through Langkawi Development Authority (LADA) with the slogan 'Naturally Langkawi'. This new brand is part of the marketing strategy outlined in the Langkawi Tourism Blueprint, which aims to position the island among the world's top ten best islands and eco-tourism destinations by 2015. Langkawi Tourism Blueprint was launched by the Malaysian Prime Minister in 2012 which outlined short term action plan that contains 14 initiatives across three themes, namely product, infrastructure and enabler and it is expected to boost the island's tourism sector via income and job generation [25].

Table 1. Slogans used in branding Langkawi as a leading global island destination from 1974 until present adapted from Andreu, Bigne and Cooper [20] and Farmaki [21].

\begin{tabular}{|c|c|c|}
\hline Year & Slogan & Main campaign features \\
\hline 1974 & $\begin{array}{l}\text { Islands of } \\
\text { legends } \\
\text { Isle of legends }\end{array}$ & $\begin{array}{l}\text { Describe in the brochure as 'the islands are shrouded with an intriguing } \\
\text { heritage of myths and legends that feature ogres and gigantic birds, } \\
\text { warriors and fairy princess, battles and romance' (Tourism Malaysia, } \\
\text { 2012) } \\
\text { Images of Eagle Square frequently featured in most brochures. Man- } \\
\text { made attraction in form of reddish brown eagle statute which is } \\
\text { prominent landmark of Langkawi Island is frequently featured in the } \\
\text { brochures. } \\
\text { Feature of long stretches of beaches of Chenang, one of the popular } \\
\text { tourists' spots for beaches activities and various waterfalls available on } \\
\text { the islands such as Temurun or Seven Wells (Telaga Tujuh). }\end{array}$ \\
\hline 1987 & $\begin{array}{l}\text { Duty free island } \\
\text { destination }\end{array}$ & $\begin{array}{l}\text { Highlight the island as a shopping destination for selling duty free } \\
\text { goods, such as chocolates, household appliances, liquor and cigarettes. }\end{array}$ \\
\hline 2001 & $\begin{array}{l}\text { Langkawi } \\
\text { Tourism City }\end{array}$ & $\begin{array}{l}\text { Emphasis as a destination with modern tourism facilities that provide } \\
\text { range of products from man-made attractions (Langkawi Cable car, } \\
\text { Underwater World, Eagle Square), special events to natural attractions. }\end{array}$ \\
\hline 2007 & $\begin{array}{l}\text { Langkawi } \\
\text { Geopark }\end{array}$ & $\begin{array}{l}\text { Attempt to raise the island tourism industry into an international level } \\
\text { and for global tourism recognition where one of its tourism products, } \\
\text { geoheritage is recognised by the UNESCO Global Geopark } \\
\text { Promote as a destination with a unique geological landscape and } \\
\text { heritage that may attract tourists from all over the world. }\end{array}$ \\
\hline 2008 & $\begin{array}{l}\text { Langkawi The } \\
\text { Jewel of Kedah }\end{array}$ & $\begin{array}{l}\text { Emphasis that Langkawi is part of Kedah state and the island has so } \\
\text { many tourism attractions to offer in terms of its natural resources and } \\
\text { man-made attractions. } \\
\text { The same images of the statue of reddish brown eagle, beaches, and } \\
\text { cable car attractions are featured in Langkawi brochures. }\end{array}$ \\
\hline 2012 & $\begin{array}{l}\text { Naturally } \\
\text { Langkawi }\end{array}$ & $\begin{array}{l}\text { Emphasis more of the island natural resources such as its unique } \\
\text { geological landscape, nice beaches and other natural features } \\
\text { Highlight various products and services which are in line with eco- } \\
\text { tourism destination } \\
\text { Aim to position the island among the world's top ten best islands and } \\
\text { eco-tourism destinations by } 2015 \text {. }\end{array}$ \\
\hline
\end{tabular}


Based on Langkawi Blueprint, approximately RM5 billions of government and private funds will directed towards the development of more accommodation, commercial zones and infrastructures between 2011 and 2015 [26]. This amount of funds and the number of project listed in the blueprint may further enhance Langkawi's projected image as a premier tourism destination in the region. However, Lee [26] concerns that such developments that may take place on the island especially the development of more new hotels and resorts and additional major infrastructures may put conservation and preservation of island natural resources at risk. Therefore, indirectly it may affect the projected image of Langkawi as an ecotourism destination if such development is not being monitored accordingly.

\section{Conclusion}

Based on the above discussion, it can be summed up that Langkawi has gone through different phases of branding and re (branding) attempts to position itself as a premier destination. In the beginning, Langkawi was aggressively promoted as the island of legend based on its myths and legends story tales. The projected image of island of legends is very successful and the tagline of Langkawi Isle of Legend was frequently used and appeared in all brochures of Langkawi Island. The island also was promoted as a duty free shopping destination considering its duty free status. Subsequently, the island becomes popular among local tourists as a shopping destination. With so many special events and number of sport competition events held on the island, Langkawi may as well be brand as MICE and special event destination. At the same time, the island is blessed with natural resources and ecotourism which it has been branded as eco-tourism destination under the brand name 'Geopark Langkawi and the latest 'Naturally Langkawi'. By frequently changing names and slogans from one to another (e.g 'Isle of Legend', Duty-free island', 'Langkawi 99 Magical Islands', 'Tourist City', 'Langkawi Geopark', 'Langkawi, Jewel of Kedah', 'Naturally Langkawi') may result in confusion not only to the visitors but also among local population. The island needs to identify its own core values in order to have a very specific brand differentiating from other established destination such as Hawaii, Bali or Phuket. However, all these brands which in the forms of slogans and taglines may represent something unique of the island but at the same time they must be supported by the internal stakeholders or otherwise they may not be sustainable. Therefore, research is needed to confirm whether all these slogans or brands are endorsed and supported by the internal stakeholders (i.e. host community, tourism operators) as well as in agreement with what as being perceived by the tourists.

\section{References}

1. C. Blain, S.E. Levy, J.R.B. Ritchie, J. Travel Res., 43, 328 (2005)

2. M. Kavaratzis, M.J. Hatch, Marketing Theory, 13, 69 (2013)

3. L. Cai, Ann. Tour. Res., 29, 720 (2002)

4. S. Hudson, J.R.B. Ritchie, IJTR, 11, 111 (2009)

5. S. Pike, Tour. Manage., 33, 100 (2012)

6. F. Wheeler, W. Frost, B. Weiler, JTTM, 28, 13 (2011)

7. M. Kavaratzis, G.J. Ashworth, PBPD, 3, 183 (2006)

8. J.D. Clark, A.E. Clark, C.E. Jones jr., JHMM, 19, 358 (2010)

9. I. Bregoli, J. Travel Res., 52, 212 (2012)

10. O.G. Ling, GeoJournal, 66, 199 (2006)

11. A. Marzuki, WASJ, 12, 25 (2011)

12. K. Kayat, IJTR, 4, 171 (2002)

13. A. Marzuki, IJHTS, 1, 1 (2008)

14. A. Marzuki, I. Hay, J. James, J. Sustainable Tour., 20, 585 (2012)

15. A. Marzuki, I. Hay, Tourism Planning \& Development, 10, 494 (2013)

16. A. Kasim, H. Dzakiria, K.T. Lim, MMJ, 3, 93 (1999) 
17. I. Othman, A.A.A. Latif, H. Omar, Asia Pac. J. Tour. Res., 6, 33 (2001)

18. N.A. Razak, Regional Conference on Tourism Research (USM, Penang, 2010)

19. Economic Planning Unit, Langkawi Island Blueprint 2011-2015 (2011)

20. L. Andreu, J.E. Bigne, C. Cooper, JTTM, 9, 47 (2001)

21. A. Farmaki, TOURISMOS, 7, 95 (2012)

22. H.S. Hashim, S. Aziz, R.A. Aziz, Planning Malaysia, 9, 1 (2011)

23. S.A. Halim, I. Komoo, H. Salleh, M. Omar, Shima: The International Journal of Research into Island Cultures, 5, 94 (2011)

24. N. Azman, S.A. Halim, O.P. Liu, S. Saidin, I. Komoo, Procedia Soc. Behav. Sci., 7, 504 (2010)

25. S.I. Omar, A.G. Othman, B. Mohamed, Int. J. Cult. Tourism Hospit. Res., 8, 272 (2014)

26. M. Lee, JOE, 12, 197 (2013) 